\title{
Cancer and Infectious Causes
}

\author{
Aaron J. Smith, John Oertle, Dino Prato \\ Envita, Scottsdale, AZ, USA \\ Email: Aaron@Envita.com, JohnO@envita.com, DinoPrato@envita.com
}

Received 4 July 2014; revised 5 August 2014; accepted 4 September 2014

Copyright (C) 2014 by authors and Scientific Research Publishing Inc.

This work is licensed under the Creative Commons Attribution International License (CC BY).

http://creativecommons.org/licenses/by/4.0/

(c) (i) Open Access

\begin{abstract}
Various kinds of organisms, including viruses, bacteria, trematodes and fungi are known carcinogens that cause cancer. Infectious identification related to cancer may lead to better treatment for both the prevention and targeting of cancer therapy. Although nearly $20 \%$ of all cancers are caused by an infection of a microbe, the amount of evidence and information regarding the mechanisms associated with oncogenesis varies dramatically from one organism to the next. This review cannot be exhaustive because we are not aware of all infections worldwide in addition to their potential mechanisms for oncogenesis. More research is required for all of the species mentioned in this review.
\end{abstract}

\section{Keywords}

Epstein Bar Virus, Hepatitis B Virus, Hepatitis C Virus, Human Herpes Virus 6, Human Herpes Virus 8, Human Papillomavirus, Human T-Cell Leukemia Virus Type 1, Merkel Cell Polyomavirus, Chlamydia pneumonia, Helicobacter pylori, Mycoplasma, Salmonella typhi-1, Streptococcus bovis, Clonorchis sinensis, Opisthorchis viverrini, Schistosoma haematobium, Aspergillus flavus, Aspergillus parasiticus, Cancer, Oncogenesis

\section{Introduction}

Out of all of the infectious diseases worldwide, there are only a few microorganisms that have a well-defined mechanism associated with oncogenesis. Many of the mechanisms hypothesized involve inflammation as a primary mechanism since inflammation is known to create an environment where there are more reactive oxygenated species in addition to providing an environment where aberrant methylation of oligonucleotides changes gene regulation from an epigenetic standpoint [1]. Occasionally there are mechanisms associated with a genetic transfer of viral DNA to the host genome, potentially causing an opportunity for mutagenesis that leads to oncogenesis [2]. Other microorganisms either provide or metabolize toxins related to mutagenesis [3]. Established oncogenes and oncoproteins are primarily limited to viral infections [4] [5]. The oncogenes involved in bacterial carcinogens are unknown since much of the information involved in the study comes from epidemiological evi- 
dence and limited molecular biological studies. This means that although there is evidence regarding the microbe's ability to promote oncogenesis, other genes responsible for the promotion of cancer remains unknown.

While treating cancer with chemotherapy and radiation are fundamental, these processes wreak havoc on the immune system. A weak immune system increases the likelihood of developing various forms of cancer. While immune surveillance is a powerful mechanism for detecting and destroying precancerous and cancerous cells, it is important to keep in mind that the immune system also fights pathogens that are known carcinogens.

\section{Viruses}

Viral infections are more commonly associated with the development of cancer when compared to bacterial, trematode, and fungal infections. Viruses are known to have oncogenic potential by inserting its DNA into the host chromosome in addition to altering the cellular signaling with viral proteins. Table 1 shows a breakdown of the known mechanisms of oncogenesis, the kinds of cancers associated with the viral infection, and treatments available. Each virus has its own characteristics or mode with regard to promoting oncogenesis.

\subsection{Epstein Barr Virus}

Epstein Barr Virus (EBV) is a gamma-1 herpes virus that is restricted to primate hosts and usually acts as a latent infection in host B lymphocytes. Although an EBV infection is typically asymptomatic, the virus has the potential inducing oncogenesis to form a wide array of tumors [6] [7]. The most common kinds of cancer caused by EBV include: Hodgkin Lymphoma, Burkitt Lymphoma, diffuse large B cell lymphoma (DLBCL), pyrothorax lymphoma, nasopharyngeal carcinoma, gastric carcinoma, and leiomyosarcoma of the immunocompromised [8]. However, healthy individuals with a typically asymptomatic EBV infection have an immune system that contains the virus via antigen specific memory CD8 T lymphocytes [9].

Oncogenes encoded by EBV include latent membrane protein 1 (LMP1) and LMP2A where LMP1 induces growth promoting signals while mimicking CD40 signaling pathways while LMP2A acts like a B cell receptor that activates AKT, NF-kB, NOTCH, and phosphatidylinositol 3 kinase [10] [11]. EBV nuclear antigen (EVBNA) 3A/C silences tumor suppressor as a mechanism associated with oncogenesis [12] [13].

\subsection{Hepatitis B Virus}

Hepatocellular carcinoma (HCC) accounts for approximately 70\% - 85\% of all types of liver cancer [14]. Liver

Table 1. The following viruses each have different mechanisms associated with oncogenesis with regard to their respective oncogenes and oncoproteins. Each virus is known to cause various forms of cancer. The known antivirals to treat each virus, if available, are listed below. Many of the known antivirals are taken in various combinations to combat a given virus.

\begin{tabular}{|c|c|c|c|}
\hline Virus & $\begin{array}{l}\text { Genes and Proteins Involved } \\
\text { in Cancer }\end{array}$ & Cancer & $\begin{array}{l}\text { Treatment Available for } \\
\text { Virus Infection }\end{array}$ \\
\hline EBV & $\begin{array}{l}\text { LMP1, LMP2A, AKT, NF-kB, } \\
\text { NOTCH, and } \\
\text { phosphatidylinositol } 3 \text { kinase }\end{array}$ & $\begin{array}{l}\text { Hodgkin Lymphoma, Burkitt Lymphoma, Diffuse } \\
\text { Large B Cell Lymphoma, Pyrothorax Lymphoma, } \\
\text { Nasopharyngeal Carcinoma, Gastric Carcinoma, } \\
\text { and Leiomyosarcoma }\end{array}$ & $\begin{array}{l}\text { No specific } \\
\text { antiviral treatment }\end{array}$ \\
\hline $\mathrm{HBV} / \mathrm{HCV}$ & $\begin{array}{c}\text { TP53, CTNNB1, AXIN, ARID1A, } \\
\text { AXIN1, and CDKN2A, and } \\
\text { ARID1A }\end{array}$ & Hepatocellular carcinoma & $\begin{array}{l}\text { Pegylated interferon, } \\
\text { ribavirin, boceprevir, } \\
\text { and telaprevir }\end{array}$ \\
\hline HHV-6 & ORF-1, p53, U95, NF-kB & $\begin{array}{l}\text { Oral Squamous Cell Carcinoma, Hodgkin’s Disease, } \\
\text { non-Hodgkin’s lymphoma, and cervical carcinoma }\end{array}$ & $\begin{array}{l}\text { No specific antiviral } \\
\text { treatment; immunotherapy }\end{array}$ \\
\hline HHV-8 & K1, vIRF, and cIL8R & $\begin{array}{c}\text { Karposi’s Sarcoma and Primary } \\
\text { Effusion Lymphoma }\end{array}$ & $\begin{array}{l}\text { Ganciclovir and } \\
\text { Foscarnet }\end{array}$ \\
\hline $\mathrm{HPV}$ & E5, E6, and E7 & Cervical Cancer & Vitamin A and curcumin \\
\hline HTLV-1 & p53 & Adult T-Cell Leukemia/Lymphoma & $\begin{array}{l}\text { Corticosteroids, } \\
\text { Plasmapheresis, } \\
\text { Cyclophosphamide, } \\
\text { Interferon, Valproic Acid, } \\
\text { and Zidovudine }\end{array}$ \\
\hline MCPyV & CD3G, CD3D, ZAP70, and IGHM & Merkel Cell Carcinomas & Nospecific antiviral treatment \\
\hline
\end{tabular}


cancer is the third leading cause of deaths associated with cancer in addition to being the sixth most common cancer [15]. The likelihood of developing HCC while infected with hepatitis B virus (HBV) is between a $2500 \%$ - 3700\% increase compared to patients without HBV [16] [17]. Elevated risk of HCC is correlated with a high viral load of HBV [18]. HBV is likely to cause liver cirrhosis and inflammation which is found in $80 \%-90 \%$ of cases of HCC [18]. The regulation of HBV proliferation in the liver involves both natural killer cells and CD8+ T cells that actively fight the HBV infection [19].

HCC has three molecular mechanisms associated with an infection of HBV [20]. The first is cell proliferation and variability from the expression of viral protein HBX [2]. The second mechanism is related to HBV DNA integration which changes the expression of endogenous genes in addition to destabilizing the chromosome of the host genome [2]. The destabilization of the host chromosome is more common in HBV infections than it is in hepatitis $\mathrm{C}$ viral (HCV) infections. The third involves the accumulation of DNA damage caused by inflammation and hepatocyte division [2].

\subsection{Hepatitis C Virus}

130 - 170 million people world-wide are infected with HCV [21]. HCV infections are associated with some degree of liver fibrosis in addition to $15 \%$ - 25\% of patients developing cirrhosis after 10 - 40 years of infection [22]. Patients with chronic hepatitis C (CHC), in addition to cirrhosis of the liver, increase the risk of liver failure and the formation of HCC [23]. Chronic infections are correlated to low NK cells titers despite the fact that NK cells usually high in the liver [24]. However, NK cells are activated and kill HCV-infected hepatocytes releasing antigens that prime specific CD8 and CD4 response [25].

Oncogenesis associated with oxidative stress has been examined in several mouse models including mice deficient in copper/zinc superoxide dismutase and mice with erythroid-2-related transcription factor-1 (Nrf1) knockout [26] [27]. Continued exposure to $\mathrm{H}_{2} \mathrm{O}_{2}$ can increase the activity of methylation of oligos, including the down regulation of catalase by affecting its promoter region [28] [29]. Increased methylation in HCC cells also respectively increases the expression of Snail [28] [30]. This methylation silences the expression of E-cadherin by a mechanism that first involves methylating the E-cadherin promoter via histone deacetylase 1 and DNA (cystosine-5)-methyltransferase 1, which increases expression of Snail [28]. The reduction of E-Cadherin is an early biomarker for both HCC and HCV-related cirrhosis [30].

\subsection{HBV and HCV Oncogenes Associated with HCC}

HBV and HCV have similar mechanisms with regard to their effect on the host chromosomes. While these oncogenes are common in HBV and HCV infections, the likelihood of developing HCC depends on the insertion of the viral genes in addition to altered bases and changes in the epigenetic profiles of the host chromosome. Common genes effected by aberrant bases in HCC during an HBV and HCV infection include TP53, CTNNB1, and AXIN. Deletions and silencing of CDKN2A in HCC tissue is also common in HBV and HCV infected patients. Mutations in tumor suppressor genes including TP53, ARID1A, AXIN1, and CDKN2A and an oncogene known as ARID1A are common in 10\% of HCC tumors [31].

\subsection{Human Herpes Virus 6}

Human Herpes Virus 6 (HHV-6) is associated with encephalitis in immunocompetent individuals, maternal fetal infections, hematological malignancies, and digestive problems in immunocompromised individuals [32]-[34]. The virus is known to infect oligodendrocytes and astrocytes in samples in vivo and in vitro in addition to being detected in brain tumors of both adult and children patients via PCR, immunohistochemistry, and in situ hybridization [35] [36]. The mechanism for oncogenesis may involve the expression of viral protein ORF-1, which can form a dimer and deactivate p53, and U95, which can bind and deactivate NF-kB [34] [37]. HHV-6 is best known for its ability to infect CD4+ T cells which may increase the immunological effect from HIV in AIDS patients [38]. The ability for HHV-6 to evade the immune system is largely due to its ability to remain dormant though the life cycle in the cell. However, the expression of viral proteins is known to alter the immunomodulation associated with the engagement of CD46 receptors as well as alter the expression of cell surface receptor in T cells [39]. 


\subsection{Human Herpes Virus 8}

At the time, presence of Human Herpes Virus 8 (HHV-8) or Kaposi's sarcoma-associated herpes virus (KSHV) was found in virtually all Kaposi's sarcoma (KS) tissue for both immune competent and incompetent patients and appeared to be specific of the virus since it was yet to be found present in nearly any other tissue or diseases [40]-[42]. HHV-8 is also found in primary effusion lymphoma (PEL) and multicentric Castleman's disease (MCD) [43]. HHV-8 viral proteins contribute to the pathogenesis and can be found in both latent and lytic phases [44]. The ability for HHV-8 to evade the immune systems comprises of many factors which include evasion of NK and T cell response, blockage of apoptotic pathways, interference of interferon signaling, and host chemokine network alterations [45].

KS is a vascular tumor that forms nodular lesions on skin and mucosa before it becomes a more aggressive form of cancer found in multicentric lesions of lymph nodes [46]. The mechanism of oncogenesis remains unclear since much of the potential oncogenes are only present in the lytic phase where the KS samples collected suggest that the HHV8 is still in latent phase [47]. These genes include K1, vIRF, and cIL8R [47]. The mechanism of HHV8 in KS is still not understood and likely involves a multistep process of oncogenesis.

\subsection{Human Papillomavirus}

The worldwide leading cause of morbidity and mortality for women is cervical cancer [48] [49]. Even though human Papillomavirus (HPV) plays a very important part in the etiology of cervical cancer, the virus itself is not completely sufficient for cancer prognosis [50] [51]. With more than $120 \mathrm{HPV}$ types, there are at least $15 \mathrm{HPV}$ types with oncogenic potential when there is a persistent infection [52] [53]. Although NK cells have the capacity of recognizing and killing virus-infected transformed cells by granule-dependent cytotoxicity and apoptotic pathways, the tumor cells associated with HPV infections evade attacks by NK cells [54]. Dendritic cells are not able to promote T-cell immune response during a HPV infection which significantly attenuates the humoral immune response [55] [56]. Many of the biomarkers associated with oncogenesis include various surface proteins of HPV [57] [58]. The most notable oncoproteins, E5, E6, and E7, initiate continuous proliferation without genetic proofreading which causes mutations that can lead to cancer [4] [5]. The regulation of HPV genome post infection likely involves gene regulation from miRNA of the host [59] [60].

\subsection{Human T-Cell Leukemia Virus Type 1}

Human T-cell Leukemia virus type 1 (HTLV-1) is one of the oldest retroviruses and the first human retrovirus to be discovered [61]. Its discovery followed an epidemiological study of Adult T-cell leukemia/lymphoma (ATLL) where the cancer appeared to have been spreading like a pathogen in Japan [62]. ATLL is an aggressive lymphoproliferative disease that can be contracted from asymptomatic individuals [63] [64]. ATLL oncogenesis involves the HTLV-1 protein Tax to quell apoptosis, initiate a cascade reaction that leads to cellular inflammation, and inhibition of p53 in a cascade associated with DNA repair respectively [65]-[68]. The reason for HTLV-1 persistence in a manner that does not trigger an innate immune response still remains a mystery. The ability to detect HTLV-1 in serum is very difficult since an infection requires the transfer from infected cells [69]. Hypothesis of HTLV-1 spreading by mitosis of infected cells is a likely reason for its ability to evade the immune system [70].

\subsection{Merkel Cell Polyomavirus}

Merkel cell Polyomavirus (MCPyV) can be found in $80 \%$ of all Merkel cell carcinomas [71] [72]. A recent study showed a small presence of MCPyV in extrapulmonary small cell carcinomas [73]. The frequency of $\mathrm{MCPyV}$, in the general population, is $80 \%$ of people who are over the age of 50 years [74]. The virus is also present in over $85 \%$ of homo- and bisexual HIV positive young men [74]. The incidence of developing MCC is very rare for immunocompetent individuals, the tumor is much more likely to occur in AIDS patients and those with chronic lymphocytic leukemia [75] [76]. Complete remission of an MCC tumor is possible for those immunosuppressed individuals who become immunocompetent [77]. MCPyV-positive tumors have up regulated CD3G, CD3D, ZAP70, and IGHM; however, the biological significance in oncogenesis remains unknown [78]. Although there is evidence of a link between ultraviolet (UV) radiation and specific mutations in TP53 and Ha-RAS, the mechanism associated with UV radiation in oncogenesis associated with MCPyV has yet to be determined [79]. 


\section{Bacteria}

Bacterial infections also contribute to the promotion of oncogenesis typically through mechanisms associated with inflammation. Although inflammation is a vague explanation of how bacteria promote oncogenesis, the bacteria none the less interfere by altering the environment surrounding tissue in a way that does promote an environment where mutations are more prominent and epigenetic gene regulation goes haywire. Table 2 also shows the various modes of oncogenesis, kinds of cancer it is likely to cause, and treatments available.

\subsection{Borrelia burgdorferi}

Borrelia burgdorferi $(\mathrm{Bb})$ is a spirochete that causes the zoonotic tick borne infection known as Lyme disease [80]. Erythema chronicum migrans (ECM), lymphocytoma cutis, and acrodermatitis chronica atrophicans (ACA) are a few of the cutaneous disorders associated with Bb infection [81]-[83]. Primary cutaneous B-cell lymphoma (PCBCL), in skin affected by ACA and patients with serology associated with previous exposure to Bb, shows evidence that PCBCL may be caused by $\mathrm{Bb}$ [84]-[86]. Bb can also be found in skin lesions of patients with PCBCL [87]-[89]. Borrilia induces a strong immunological response but has the ability to stave off the immune system despite dendritic cell (DC) activation and recognition of Bb surface lipoproteins [90]. The DC response is coupled with various effector T-cells.

\subsection{Chlamydia pneumoniae}

Chlamydia pneumoniae is an intracellular parasite, gram negative bacillus, and causes infection in $50 \%$ of adults exposed to the pathogen [91] [92]. The bacteria are transmitted through aerosol and respiratory secretions [91] [93]. An infection with C. pneumoniae can cause pneumonia, bronchitis, rhinitis, sinusitis, COPD or an asymptomatic infection. C. pneumoniae has the ability to evade innate immunity involving type 1 IFN by restricting the phosphorylation and nuclear translocation of IRF3 [94].

Although the mechanism for $C$. pneumoniae to cause lung cancer is unknown, there are a few possible mechanism associated with its oncogenisis. One possible mechanism involves mediators associated with inflammation [95]. Inflammation can cause damage of DNA through reactive oxygenated species. Inflammation can also damage cells including the cells ability to repair itself in addition to increasing the rate of cellular division [96]. C. pneumoniae can localize and infect preferentially to the lungs of smokers [97]. Monocytes secretion of IL-1 $\beta$, IL-8, superoxide oxygen radicals, and tumor necrosis factor act as mediators of inflammation and can also cause damage to lung tissue and DNA which can result in carcinogenesis [98].

Table 2. Mechanisms of each bacteria is either known to cause cancer with regard to specific oncogenes, the toxins produced or metabolized by the host, or is likely caused by mechanisms associated with inflammation. The loci of the various bacteria is generally proximal to the region associated with the cancer. The various treatment options are often taken in combination to treat bacterial infection in a manner that minimizes the opportunity for the bacteria to become resistant to antibiotics.

\begin{tabular}{|c|c|c|c|}
\hline Bacteria & Mode of Oncogenesis & Types of Cancers & Treatment Available for Bacterial Infections \\
\hline $\begin{array}{c}\text { Borrelia } \\
\text { burgdorferi }\end{array}$ & $\begin{array}{l}\text { Oncogenes Unknown/ } \\
\text { Inflammation }\end{array}$ & $\begin{array}{l}\text { Primary Cutaneous } \\
\text { B-Cell Lymphoma }\end{array}$ & $\begin{array}{l}\text { Doxycycline, Amoxicillin, Cefuroxime } \\
\text { Axetil, Ceftriaxone and Penicillin. }\end{array}$ \\
\hline $\begin{array}{l}\text { Chlamydia } \\
\text { pneumoniae }\end{array}$ & $\begin{array}{l}\text { Oncogenes Unknown/ } \\
\text { Inflammation }\end{array}$ & Lung Cancer & $\begin{array}{l}\text { Macrolides, Doxycycline, } \\
\text { and Quinolones }\end{array}$ \\
\hline $\begin{array}{l}\text { Helicobacter } \\
\text { pylori }\end{array}$ & $\begin{array}{l}\text { Oncogenes Unknown/ } \\
\text { Inflammation }\end{array}$ & Gastric Carcinoma & $\begin{array}{l}\text { Amoxicillin, Clarithromycin, Lansoprazole, } \\
\text { Omeprazole, Metronidazole, Bismuth Subsalicylate, } \\
\text { Metronidazole, and Tetracycline }\end{array}$ \\
\hline Mycoplasma & $\begin{array}{l}\text { P53 suppression, NF-kB activation, } \\
\text { and inducing genetic instability }\end{array}$ & $\begin{array}{l}\text { Gastric and } \\
\text { Colon Carcinoma }\end{array}$ & $\begin{array}{l}\text { Azithromycin, Clarithromycin, } \\
\text { and Erythromycin }\end{array}$ \\
\hline $\begin{array}{l}\text { Salmonella } \\
\text { typhi-1 }\end{array}$ & $\begin{array}{c}\text { Deconjugation of toxins and bile acid } \\
\text { as a byproduct of glucuronidase and } \\
\text { bind to DNA causing mutagenesis } \\
\text { and inflammation }\end{array}$ & Cholangiocarcinoma & $\begin{array}{c}\text { Ampicillin, Trimethoprim-Sulfamethoxazole, } \\
\text { Chloramphenicol Quinolone, Macrolide, } \\
\text { and Cephalosporin }\end{array}$ \\
\hline $\begin{array}{l}\text { Streptococcus } \\
\text { bovis }\end{array}$ & $\begin{array}{c}\text { Oncogenes Unknown/Carcinogenic } \\
\text { Byproducts and Inflammation }\end{array}$ & Colorectal Cancer & $\begin{array}{l}\text { Penicillin G, Ceftriaxone, } \\
\text { and Gentamicin }\end{array}$ \\
\hline
\end{tabular}




\subsection{Helicobacter pylori}

Helicobacter pylori chronic infections are associated with peptic ulcerations and atrophic gastritis in addition to being associated with the development of gastric carcinoma, which is the second leading cause of deaths related to cancer in the world [99] [100]. Most $H$. pylori infected individuals are asymptomatic and never develop neoplasms even though $\mathrm{H}$ pylori infection is very prevalent in patients with gastric cancer [101]. It is important to note that there are an abundant amount of $H$. Pylori strains and many individuals harbor more than one strain [102]-[104]. H. Pylori induces a robust immune response associated with an increase in IL-1, IL-8, and IL-6 concentration [105]. An increase in the number of CD4 and CD8 T-cells of infected individuals as compared to pre-infected individuals is also common [106].

The mechanism for oncogenesis associated with gastric carcinoma is unknown. However, $\mathrm{H}$ pylori's association with chronic inflammation, which leads to aberrant methylation genes including tumor suppressor genes, suggest a potential epigenetic mechanism is involved [107] [108]. Human gastric mucosae have high levels of methylation in the presence of $H$. pylori [109] [110].

\subsection{Mycoplasma}

Mycoplasma is the smallest self-replicating prokaryote and acts as a parasite that infects vertebrates. An infection of Mycoplasma can alter the cellular metabolism and physiology of a host and can act as an opportunistic pathogen under rare circumstances [111] [112]. Chronic Mycoplasma infections have the capacity to induce genetic instability and malignant transformation [113]-[118]. The metastasis of tumor cells can be influenced by the presence of Mycoplasma in vivo in addition to being a factor in increasing the invasiveness of tumors in vitro [114] [116] [118]. P53 suppression and NF-kB activation are influenced by an infection of Mycoplasma [119]. Although there are studies that begin to correlate the effect of Mycoplasma to various cancers, the results remain in conjecture.

\subsection{Salmonella typhi-1}

The presence of cholangiocarcinoma is common Southeast Asia, Japan, Chile, Bolivia, and northern India [120]-[124]. Cholangiocarcinoma is of greater risk if the patient has gallstones [125] [126]. However, patients that are chronic typhoid are 167 times more likely to develop cholangiocarcinoma [127].

There are several potential mechanisms associated with the development of cholangiocarcinoma from Salmonella typhi. The first mechanism is associated with cholangiocarcinoma formation involves the deconjugation of conjugated toxins and bile acid to form carcinogenic biproducts by the enzyme $\beta$-glucuronidase of the bacteria [128] [129]. These byproducts of glucuronidase are mutagens that bind to DNA and create the opportunity for oncogenesis [3]. Chronic typhoid carriers that are not treated by antibiotics have an increased concentration of free radicals, which are known to promote oncogenesis [130]. The site of the infection of S. typhi-1 is known to cause inflammation [131]. It is also important to note that $S$. typhi-1 infection has the capacity to survive macrophage phagocytosis [132]. The lifetime of the S. typhi-1 and its overall effect on macrophages remains unclear.

\subsection{Streptococcus bovis}

Streptococcus bovis is a bacteria that is commonly associated with colorectal cancer. Although there is some discrepancy on the prevalence of $S$. bovis and the rate of colorectal tumors, there is evidence that $25 \%-80 \%$ of those infected with $S$. bovis have colorectal tumors with $18 \%$ - 62\% having colonic neoplasia [133]-[139]. The etiology of the development of cancer associated with a bacterial infection usually involves chronic inflammation and the production of carcinogenic metabolites [140]. Many cancers associated with bacterial infections originate at the sight of the infection, causing chronic irritation, and inflammation [141]. Finding the proper metabolite in the microbiome, where there is a lot of competing floras, is very difficult but there remains a potential for the bacteria to create a microclimate that allows mutagens to flourish [140].

\section{Trematodes}

Trematodes act as microscopic parasites that use the host as a means to feed and reproduce. Often times the host 
will excrete the eggs of the trematodes through feces and urine. The majority of trematode infections occur in the Asia-pacific region and are a consumed through either undercooked fresh water fish or contaminated drinking water. Table 3 describes what is known about the mechanism associated with oncogenesis as well as describes what the kind of cancers the trematodes induce in addition to known treatments.

\subsection{Clonorchis sinensis}

Clonorchis sinensis is a hermaphroditic trematonde liver fluke found primarily in Southeast Asia. C. sinensis was reported to have infected 7 million people in southern China, Korea, Taiwan, and Vietnam [142]. The liver fluke is commonly transmitted by consuming the muscle and connective tissue of undercooked fresh water fish in the endemic region. The matured worms begin to attach to intrahepatic bile ducts and sometimes even the gall-bladder and pancreatic duct [143]. C. sinensis is known to cause biliary tree inflammation, epithelial cell hyperplasia, mucin-producing cells in the mucosa mataplasia, and periductal fibrosis [144]-[148]. The second most prevalent liver cancer is cholangiocarcinoma behind only hepatocellular carcinoma. C. sinensis can cause an inflammatory response that induces the likelihood of forming cholangiocarcinoma [149]. Although rats are resistant to $C$. sinensis, the resistance is not from specific immunity and instead involves primarily local inflammation [150].

\subsection{Opisthorchis viverrini}

Opsithorchis viverrini is a food borne trematode that transmits by ingesting the fins, skin, or musculature of raw or undercooked fish. The liver fluke is endemic in Thailand, Vietnam, Cambodia, and Lao [151] [152]. O. viverrini is associated with conditions including obstructive jaundice, periductal fibrosis, cholelithiasis, cholangitis, and hepatomegaly [153]. O. Viverrini is linked with the etiology of cholangiocarcinoma (CCA), as studied by epidemiological and experimental evidence [152] [154]-[156]. The leading cause of cancer mortality in Southeast Asia is CCA. There are multiple mechanisms for oncogenesis associated with an O. viverrini which include mechanical injury of epithelial cells, immunopathology associated with infection related inflammation, and the toxic excretory/secretory (ES) molecules from the parasite [157].

\subsection{Schistosoma haematobium}

Schistosomiasis is the second leading cause of morbidity and mortality of a parasitic disease after malaria [158]. The disease affects $10 \%$ of the world's population and is usually picked up by drinking water contaminated with Schitosoma haematobium in sub-Saharan Africa [159] [160]. The geographic areas that are endemic to S. haematobium have elevated numbers of bladder carcinomas. S. haematobium has both the ability to evade host immunity in addition to being able to effect the hormonal microenvironment in a way that suits its reproduction and growth [156].

The potential mechanisms of oncogenesis bladder carcinomas involve either environmental factors or the N-nitroso compounds associated with bladder inflammation [157]-[162]. The environmental factors including pesticides and cigarette smoke have the potential to work synergistically with $S$. haematobium infection by increasing the likelihood of bladder carcinoma [162] [163]. N-nitroso compounds are found in excess in the urine of infected individuals [164]-[167]. These compounds have been hypothesized to have come from endogenous

Table 3. The mechanism for oncogenesis are relatively unknown for trematodes. Opisthorchisviverrini excretes toxic cytokines which promote oncogenesis. However, most trematodes presence causes inflammation in the sight where the trematode has attached itself to; generally causing cholangiocarcinoma in that loci. Treatment of trematodes early significantly reduces the opportunity for oncogenesis.

\begin{tabular}{cccc}
\hline Trematodes & Mode of Oncogenesis & Cancer & Treatment for Trematode Infection \\
\hline $\begin{array}{c}\text { Clonorchis } \\
\text { sinensis }\end{array}$ & $\begin{array}{c}\text { Oncogenes Unknown/ } \\
\text { Inflammation }\end{array}$ & $\begin{array}{c}\text { Triclabendazole, praziquantel, bithionol, } \\
\text { albendazole, levamisole, and mebendazole }\end{array}$ \\
$\begin{array}{c}\text { Opisthorchis } \\
\text { viverrini }\end{array}$ & $\begin{array}{c}\text { Mechanical Injury of Epithelial Cells, } \\
\text { Inflammation, and Toxic Excretory/ } \\
\text { Secretory Molecules }\end{array}$ & Cholangiocarcinoma & Praziquantel and Tribendimidine \\
$\begin{array}{c}\text { Schistosoma } \\
\text { haematobium }\end{array}$ & Oncogenes Unknown/Inflammation & Bladder carcinoma & Praziquantel and Biltricide \\
\hline
\end{tabular}


and exogenous sources. A potential endogenous source might be associated with the inflammatory response of the bladder while an exogenous source might come from the diet of the individual [166] [167].

\section{Fungi}

Fungi is not typically associated as being carcinogenic, however, Asperigillus flavus and Asperigillus parasiticus are attributed to the development of hepatocellular carcinoma. The known treatments and mechanisms are mentioned in Table 4.

\section{Asperigillus flavus and Asperigillus parasiticus}

Asperigillus flavus and Aspergillus parasiticus are pathogenic fungi that are known to produce carcinogenic and mutagenic Aflotoxins B1 (AFB1) [168] [169]. AFB1 is a hepatocarinogen that is causally-related to the formation of hepatocellular carcinoma (HCC) [170]. HCC is a common form of cancer that accounts for $9.2 \%$ of all cancer formation [171]. HCC is seventh most common cancer in females and the fifth leading cause of cancer in males [172]. Epidemiological studies show a greater prevalence of HCC in regions where the fungus grows best; such as sub-Saharan Africa and Asia-Pacific regions [169]. The prognosis of HCC for the population of these regions is grim with $93 \%$ of those with tumors dying 12 months after the first symptoms [171]. These infections are in spite of a robust immune response comprising of both innate and adaptive mechanisms.

Possible mechanisms associated with the formation of HCC with regard to the exposure of AFB1 are thought to involve the 249ser mutation. This mutation is found in approximately between $36.3 \%$ and $66 \%$ of the patients with a lot of exposure to AFB1 [173]-[178]. In vitro research has shown a preferential codon switch associated with the mutagenesis of p53 at the third base of codon 249 [179].

\section{Discussion}

It is clear that there are many pathogens that have the capability of inducing oncogenesis. It is also clear that more research is necessary to find more infectious causes of cancer, to better understand the mechanism of oncogenesis, and to delineate treatments that target both the cancer and the infectious cause of cancer.

Of the microbes and trematodes listed in this article, there are most likely many more pathogens that could act as a carcinogen. Many of these oncogenic pathogens require extended exposure to the host organism in order to create the conditions necessary for the development of cancer. Being able to prevent the spread of theses microbes and trematodes can reduce the likelihood of people who get infected, thus reducing the opportunity for an infection to become cancerous. Treating long term infections from microbes and trematodes could pay dividends since the treatment could have a direct or tertiary opportunity to reduce the risk associated with prolonged exposures of organisms that could induce oncogenesis.

The immune system plays a major role in reducing the opportunity for an infection to cause cancer. HIV AIDS patients are more likely to acquire Karposi sarcoma (herpes virus 8), Hodgkin's and non-Hodgkin's lymphoma (EBV), liver cancer (HBV and HCV), and anal and cervical cancer (HPV) [180]. Therefore, a healthy immune system can significantly reduce the risk of acquiring a cancer from viral oncogenic pathogens.

Diseases like malaria can increase the likelihood of developing endemic Burkitt lymphoma by creating an environment of either T-cell suppression and/or a mechanism associated with stimulation of B-cells [181] [182]. The prevalence of developing endemic Burkitt lymphoma could be reduced by taking artemisinin to protect patients against malaria. Suppression of the immune system by a pathogen like Asperigillus flavus and Asperigillus parasiticus via heptocarcinogenic AFB1 toxin, reduces the opportunity for a healthy immune system to fight off the infection associated with carcinogenic fungi [183].

Table 4. Aspergillus flavus and Aspergillus parasiticus both have similar mechanisms with regard to oncogenesis in addition to similar forms of cancer and treatment.

\begin{tabular}{|c|c|c|c|}
\hline Fungi & Mode of Oncogenesis & Types of Cancers & Treatment for Fungal Infection \\
\hline $\begin{array}{l}\text { Asperigillus } \\
\text { flavus and } \\
\text { Asperigillus } \\
\text { parasiticus }\end{array}$ & $\begin{array}{l}\text { Aflotoxin Production, 249ser } \\
\text { Mutation, and Potentially a } \\
\text { Mutation in p53 }\end{array}$ & Hepatocellular Carcinoma & Voriconazole and Amphotericin B \\
\hline
\end{tabular}


Vaccines against HPV are aimed primarily at preventing mechanisms associated with the development of cervical cancer. Modalities for treating the cause of cancer by protecting the patient from an oncogenic virus are a significant step toward preventative measures against certain cancers by vaccines. However, gynecological screening alone might be the best preventative measure from cervical cancer.

On the other hand, treating the cancer with chemotherapy can reduce the body's ability to fight off infections in a way that allows opportunistic infections, associated with the development of cancer, to thrive unregulatedly. This is particularly true with HBV infections where chemotherapy reduces the body's ability to regulate thespread of HBV [184]. In addition to chemotherapy, immunotherapy might be necessary to help stave off infectious causes of cancer while treating the cancer itself.

Inflammation and oxidative stress need to be more thoroughly investigated with regard to cancer causing infections, particularly with bacterial infections. Although the causation of oncogenesis from an inflammatory response has been deliberated, the effect it has on the molecular biology of organisms is relatively unknown. The oncogenes, genetic damage, epigenetic malfunction, and tumor suppresser genes are understood to be contributing factors to cancer caused by inflamation but the details of how these microorganisms and trematodes remains a mystery. We suggest that a significant amount of research is necessary to elucidate what is really happening in cells with regard to oncogenesis and metastasis.

Screening of infectious diseases that cause cancer should become more readily available to patients, particularly in regions where individuals are more likely to be infected by oncogenic microorganisms or trematodes. Although HPV is commonly screened with regard to cervical cancer, many other carcinogenic microorganisms do not have the same kind of attention. Although many of the viral treatments associated in combatting oncoviruses are not available in addition to being asymptomatic, there should at least be screening to alert the patient that they have an elevated risk of contracting cancer.

\section{References}

[1] Jones, P.A. and Baylin, S.B. (2007) The Epigenomics of Cancer. Cell, 128, 683-692. http://dx.doi.org/10.1016/j.cell.2007.01.029

[2] Hoang, H., Akihiro, T. and Norifumi, K. (2014) Role of Hepatitis B Virus DNA Integration in Human Hepatocarcinogenesis. World Journal Gastroenterology, 20, 6236-6243. http://dx.doi.org/10.3748/wjg.v20.i20.6236

[3] Kinoshita, N. and Gelboin, H.V. (1978) Beta-Glucuronidase Catalyzed Hydrolysis of Benzoapyrene-3-Glucuronide and Binding of DNA. Science, 199, 307-309. http://dx.doi.org/10.1126/science.619459

[4] Haller, K., Stubenrauch, F. and Pfister, H. (1995) Differentiation-Dependent Transcription of the Epidermodysplasia Verruciformis-Associated Human Papillomavirus Type 5 in Benign Lesions. Virology, 214, 245-255. http://dx.doi.org/10.1006/viro.1995.0028

[5] McLaughlin-Drubin, M.E. and Munger, K. (2009) Oncogenic Activities of Human Papillomaviruses. Virus Research, 143, 195-208. http://dx.doi.org/10.1016/j.virusres.2009.06.008

[6] Young, L.S. and Rickinson, A.B. (2004) Epstein-Barr Virus: 40 Years on. Nature Review Cancer, 4, 757-768. http://dx.doi.org/10.1038/nrc1452

[7] Knipe, D.M., Howley, P.M., Cohen, J.I., Griffith, D.E., Lamb, R.A., Martin, M.A., Racaniello, V. and Roizman, B. (2013) Fields Virology. 6th Edition, Lippincott Williams \& Wilkins, Philadelphia, 1898-1959.

[8] Rickinson, A.B. (2014) Co-Infections, Inflammation, and Oncogenesis: Future Directions for EBV Research. Seminars in Cancer Biology, 26, 99-115. http://dx.doi.org/10.1016/j.semcancer.2014.04.004

[9] Rickinson, A.B. and Moss, D.J. (1997) Human Cytotoxic T Lymphocyte Responses to Epstein-Barr Virus Infection. Annual Review Immunology, 15, 405-431. http://dx.doi.org/10.1146/annurev.immunol.15.1.405

[10] Soni, V., Cahir-McFarland, E. and Kieff, E. (2007) LMP1 TRAFficking Activates Growth and Survival Pathways. Advances in Experimental Medicine and Biology, 597, 173-187. http://dx.doi.org/10.1007/978-0-387-70630-6_14

[11] Portis, T., Ikeda, M. and Longnecker, R. (2004) Epstein-Barr Virus LMP2A: Regulating Cellular Ubiquitination Processes for Maintenance of Viral Latency? Trends in Immunology, 25, 422-426. http://dx.doi.org/10.1016/j.it.2004.05.009

[12] Maruo, S., Zhao, B., Johannsen, E., Kieff, E., Zou, J. and Takada, K. (2011) Epstein-Barr Virus Nuclear Antigens 3C and 3A Maintain Lymphoblastoid Cell Growth by Repressing $\mathrm{p} 16^{\mathrm{INK} 4 \mathrm{~A}}$ and $\mathrm{p} 14^{\mathrm{ARF}}$ Expression. Proceedings of the National Academy of Sciences of the United States of America, 108, 1919-1924. http://dx.doi.org/10.1073/pnas.1019599108

[13] Skalska, L., White, R.E., Parker, G.A., Sinclair, A.J., Paschos, K. and Allday, M.J. (2013) Induction of p16 ${ }^{\text {INK4a }}$ Is the 
Major Barrier to Proliferation When Epstein-Barr Virus (EBV) Transforms Primary B-cells into Lymphoblastoid Cell Lines. PLoS Pathogens, 9, e1003187. http://dx.doi.org/10.1371/journal.ppat.1003187

[14] Perz, J.F., Armstrong, G.L., Farrington, L.A., Hutin, Y.J. and Bell, B.P. (2006) The Contributions of Hepatitis B Virus and Hepatitis C Virus Infections to Cirrhosis and Primary Liver Cancer Worldwide. Journal of Hepatology, 45, 529538. http://dx.doi.org/10.1016/j.jhep.2006.05.013

[15] Center, M.M. and Jemal, A. (2011) International Trends in Liver Cancer Incidence Rates. Cancer Epidemiology Biomarkers \& Prevention, 20, 2362-2368. http://dx.doi.org/10.1158/1055-9965.EPI-11-0643

[16] Hassan, M.M., Hwang, L.Y., Hatten, C.J., Swaim, M., Li, D., Abbruzzese, J.L., Beasley, P. and Patt, Y.Z. (2002) Risk Factors for Hepatocellular Carcinoma: Synergism of Alcohol with Viral Hepatitis and Diabetes Mellitus. Hepatology, 36, 1206-1213. http://dx.doi.org/10.1053/jhep.2002.36780

[17] Sun, C.A., Wu, D.M., Lin, C.C., Lu, S.N., You, S.L., Wang, L.Y., Wu, M.H. and Chen, C.J. (2003) Incidence and Cofactors of Hepatitis C Virusrelated Hepatocellular Carcinoma: A Prospective Study of 12,008 Men in Taiwan. American Journal of Epidemiology, 157, 674-682. http://dx.doi.org/10.1093/aje/kwg041

[18] Llovet, J.M., Burroughs, A. and Bruix, J. (2003) Hepatocellular Carcinoma. The Lancet, 362, 1907-1917. http://dx.doi.org/10.1016/S0140-6736(03)14964-1

[19] Schuch, A., Hoh, A. and Thimme, R. (2014) The Role of Natural Killer Cells and CD8 ${ }^{+}$T Cells in Hepatitis B Virus Infections. Frontiers in Immunology, 5, 258.

[20] Zucman-Rossi, J. and Laurent-Puig, P. (2007) Genetic Diversity of Hepatocellular Carcinomas and Its Potential Impact on Targeted Therapies. Pharmacogenomics, 8, 997-1003. http://dx.doi.org/10.2217/14622416.8.8.997

[21] Lavanchy, D. (2009) The Global Burden of Hepatitis C. Liver International, 29, 74-81. http://dx.doi.org/10.1111/j.1478-3231.2008.01934.x

[22] Lauer, G.M. and Walker, B.D. (2001) Hepatitis C Virus Infection. The New England Journal of Medicine, 345, 41-52. http://dx.doi.org/10.1056/NEJM200107053450107

[23] El-Serag, H.B. (2012) Epidemiology of Viral Hepatitis and Hepatocellular Carcinoma. Gastroenterology, 142, 12641273. http://dx.doi.org/10.1053/j.gastro.2011.12.061

[24] Corado, J., Toro, F., Rivera, H., Bianco, N.E., Deibis, L. and De Sanctis, J.B. (1997) Impairment of Natural Killer (NK) Cytotoxic Activity in Hepatitis C Virus (HCV) Infection. Clinical \& Experimental Immunology, 109, 451-457. http://dx.doi.org/10.1046/j.1365-2249.1997.4581355.x

[25] Abdel-Hakeem, M.S. and Shoukry, N.H. (2014) Protective Immunity against Hepatitis C: Many Shades of Gray. Frontiers in Immunology, 5, 274.

[26] Elchuri, S., Oberley, T.D., Qi ,W., Eisenstein, R.S., Roberts, L.J., Van Remmen, H., et al. (2005) CuZnSOD Deficiency Leads to Persistent and Widespread Oxidative Damage and Hepatocarcinogenesis Later in Life. Oncogene, 24, 367380. http://dx.doi.org/10.1038/sj.onc.1208207

[27] Xu, Z., Chen, L., Leung, L., Yen, T.S., Lee, C. and Chan, J.Y. (2005) Liver-Specific Inactivation of the Nrf1 Gene in Adult Mouse Leads to Nonalcoholic Steatohepatitis and Hepatic Neoplasia. Proceedings of the National Academy of Science the United States of America, 102, 4120-4125. http://dx.doi.org/10.1073/pnas.0500660102

[28] Lim, S.O., Gu, J.M., Kim, M.S., Kim, H.S., Park, Y.N., Park, C.K., et al. (2008) Epigenetic Changes Induced by Reactive Oxygen Species in Hepatocellular Carcinoma: Methylation of the E-Cadherin Promoter. Gastroenterology, 135, 2128-2140. http://dx.doi.org/10.1053/j.gastro.2008.07.027

[29] Min, J.Y., Lim, S.O. and Jung, G. (2011) Downregulation of Catalase by Reactive Oxygen Species via Hypermethylation of CpG Island II on the Catalase Promoter. FEBS Letters, 584, 2427-2432. http://dx.doi.org/10.1016/j.febslet.2010.04.048

[30] Llovet, J.M., Chen, Y., Wurmbach, E., Roayaie, S., Fiel, M.I., Schwartz, M., et al. (2006) A Molecular Signature to Discriminate Dysplastic Nodules from Early Hepatocellular Carcinoma in HCV Cirrhosis. Gastroenterology, 131, 1758-1767. http://dx.doi.org/10.1053/j.gastro.2006.09.014

[31] Forbes, S.A., Tang, G., Bindal, N., Bamford, S., Dawson, E., Cole, C., et al. (2010) COSMIC (the Catalogue of Somatic Mutations in Cancer): A Resource to Investigate Acquired Mutations in Human Cancer. Nucleic Acids Research, 38, D652-D657. http://dx.doi.org/10.1093/nar/gkp995

[32] Revest, M., Minjolle, S., Veyer, D., Lagathu, G., Michelet, C. and Colimon, R. (2011) Detection of HHV-6 in over a Thousand Samples: New Types of Infection Revealed by an Analysis of Positive Results. Journal of Clinical Virology, 51, 20-24. http://dx.doi.org/10.1016/j.jcv.2011.02.001

[33] Yao, K., Crawford, J.R., Komaroff, A.L., Ablashi, D.V. and Jacobson, S. (2010) Review Part 2: Human Herpesvirus-6 in Central Nervous System Diseases. Journal of Medical Virology, 82, 1669-1678. http://dx.doi.org/10.1002/jmv.21861 
[34] Ablashi, D.V., Devin, C.L., Yoshikawa, T., Lautenschlager, I., Luppi, M., Kühl, U. and Komaroff, A.L. (2010) Review Part 3: Human Herpesvirus-6 in Multiple Non-Neurological Diseases. Journal of Medical Virology, 82, 1903-1910. http://dx.doi.org/10.1002/jmv.21860

[35] Chan, P.K., Ng, H.K. and Cheng, A.F. (1999) Detection of Human Herpesviruses 6 and 7 Genomic Sequences in Brain Tumours. Journal of Clinical Pathology, 52, 620-623. http://dx.doi.org/10.1136/jcp.52.8.620

[36] Crawford, J.R., Santi, M.R., Thorarinsdottir, H.K., Cornelison, R., Rushing, E.J., Zhang, H., Yao, K., Jacobson S. and Macdonald, T.J. (2009) Detection of Human Herpesvirus-6 Variants in Pediatric Brain Tumors: Association of Viral Antigen in Low Grade Gliomas. Journal of Clinical Virology, 46, 37-42. http://dx.doi.org/10.1016/j.jcv.2009.05.011

[37] Doniger, J., Muralidhar, S. and Rosenthal, L.J. (1999) Human Cytomegalovirus and Human Herpesvirus 6 Genes That Transform and Transactivate. Clinical Microbiology Review, 12, 367-382.

[38] Knox, K.K. and Carrigan, D.R. (1996) Active HHV-6 Infection in the Lymph Nodes of HIV-Infected Patients: In vitro Evidence That HHV-6 Can Break HIV Latency. Journal of Acquired Immune Deficiency Syndrome Human Retrovirology, 11, 370-378. http://dx.doi.org/10.1016/S1386-6532(06)70004-X

[39] Lusso, P. (2006) HHV-6 and the Immune System: Mechanism of Immunomodulation and Viral Escape. Journal of Clinical Virology, 37, S4-S10. http://dx.doi.org/10.1016/S1386-6532(06)70004-X

[40] Moore, P.S. and Chang, Y. (1995) Detection of Herpesvirus-Like DNA Sequences in Kaposi's Sarcoma Lesions from Persons with and without HIV Infection. The New England Journal of Medicine, 332, 1181-1185. http://dx.doi.org/10.1056/NEJM199505043321801

[41] Boshoff, C., Whitby, D., Hatziionnou, T., Fisher, C., van der Walt, J., Hatzakis, A., Weiss, R. and Schulz, T. (1995) Kaposi's-Sarcoma-Associated Herpesvirus in HIV-Negative Kaposi’s Sarcoma. The Lancet, 345, 1043-1044. http://dx.doi.org/10.1016/S0140-6736(95)90780-7

[42] Schalling, M., Ekman, M., Kaaya, E.E., Linde, A. and Biberfeld, P. (1995) A Role for a New Herpes Virus KSHV in Different Forms of Kaposi's Sarcoma. Nature Medicine, 1, 707-708. http://dx.doi.org/10.1038/nm0795-707

[43] Chang, Y., Cesarman, E., Pessin, M.S., Lee, F., Culpepper, J., Knowles, D.M. and Moore, P.S. (1994) Identification of Herpesvirus-Like DNA Sequences in AIDS-Associated Kaposi’s Sarcoma. Science, 266, 1865-1869. http://dx.doi.org/10.1126/science.7997879

[44] Ganem, D. (2006) KSHV Infection and the Pathogenesis of Kaposi’s Sarcoma. Annual Review of Pathology, 1, 273296. http://dx.doi.org/10.1146/annurev.pathol.1.110304.100133

[45] Liang, C., Lee, J.C. and Jung, J.U. (2008) Immune Evasion in Kaposi’s Sarcoma-Associated Herpes Virus Associated Oncogenesis. Seminars in Cancer Biology, 18, 423-436. http://dx.doi.org/10.1016/j.semcancer.2008.09.003

[46] Friedman-Kien, A.E. (1981) Disseminated Kaposi’s Sarcoma Syndrome in Young Homosexual Men. Journal of the American Academy of Dermatology, 5, 468-471. http://dx.doi.org/10.1016/S0190-9622(81)80010-2

[47] Neipel, F. and Fleckenstein, B. (1999) The Role of HHV-8 in Kaposi’s Sarcoma. Seminars in Cancer Biology, 9, 151164. http://dx.doi.org/10.1006/scbi.1999.0129

[48] Walboomers, J.M., Jacobs, M.V., Manos, M.M., Bosch, F.X., Kummer, J.A., Shah, K.V., et al. (1999) Human Papillomavirus Is a Necessary Cause of Invasive Cervical Cancer Worldwide. Journal of Pathology, 189, 12-19.

[49] Pandey, S., Mishra, M. and Chandrawati, C. (2012) Human Papillomavirus Screening in North Indian Women. Asian Pacific Journal of Cancer Prevention, 13, 2643-2646. http://dx.doi.org/10.7314/APJCP.2012.13.6.2643

[50] Hausen, H. (2002) Papillomaviruses and Cancer: From Basic Studies to Clinical Application. National Reviews Cancer, 2, 342-350. http://dx.doi.org/10.1038/nrc798

[51] Pandey, S., Mittal, R.D., Srivastava, M., Srivastava, K. and Mittal, B. (2010) Cyclooxygenase-2 Gene Polymorphisms and Risk of Cervical Cancer in North Indian Population. International Journal of Gynaecological Cancer, 20, 625-630. http://dx.doi.org/10.1111/IGC.0b013e3181c63f79

[52] Muñoz, N., Bosch, F.X., de Sanjosé, S., Herrero, R., Castellsagué, X., Shah, K.V., et al. (2003) Epidemiologic Classification of human Papillomavirus Types Associated with Cervical Cancer. The New England Journal of Medicine, 348, 518-527. http://dx.doi.org/10.1056/NEJMoa021641

[53] Bosh, F.X. and de Sanjosé, S. (2003) Chapter 1: Human Papillomavirus and Cervical Cancer—Burden and Assessment of Causality. Journal of National Cancer Institute, Monographs, 2003, 3-13. http://dx.doi.org/10.1093/oxfordjournals.jncimonographs.a003479

[54] Sutlu, T. and Alici, E. (2009) Natural Killer Cell-Based Immunotherapy in Cancer: Current Insights and Future Prospects. Journal International Medicine, 266, 154-181. http://dx.doi.org/10.1111/j.1365-2796.2009.02121.x

[55] Munn, D.H., Sharma, M.D., Hou, D., Baban, B., Lee, J.R., Antonia, S.J., Messina, J.L., Chandler, P., Koni, P.A. and Mellor, A.L. (2004) Expression of Indoleamine 2,3-Dioxygenase by Plasmacytoid Dendritic Cells in Tumor-Draining Lymph Nodes. Journal of Clinical Investigation, 114, 280-290. http://dx.doi.org/10.1172/JCI200421583 
[56] Sharma, M.D., Baban, B., Chandler, P., Hou, D.Y., Singh, N., Yagita, H., Azuma, M., Blazar, B.R., Mellor, A.L. and Munn, D.H. (2007) Plasmacytoid Dendritic Cells from Mouse Tumor-Draining Lymph Nodes Directly Activate Mature Tregs via Indoleamine 2,3-Dioxygenase. Journal of Clinical Investigation, 117, 2570-2582. http://dx.doi.org/10.1172/JCI31911

[57] Pinto, A.P., Degen, M., Villa, L.L. and Cibas, E.S. (2012) Immunomarkers in Gynecologic Cytology: The Search for the Ideal "Biomolecular Papanicolaou Test”. Acta Cytologica, 56, 109-121. http://dx.doi.org/10.1159/000335065

[58] Stanley, M. (2003) Genital Human Papillomavirus Infection-Current and Prospective Therapies. Journal of National Cancer Institute, Monographs, 2003, 117-124. http://dx.doi.org/10.1093/oxfordjournals.jncimonographs.a003473

[59] Nasioutziki, M., Daniilidis, A., Dinas, K., Kyrgiou, M., Valasoulis, G., Loufopoulos, P.D., Paraskevaidis, E., Loufopoulos, A. and Karakitsos, P. (2011) The Evaluation of p16 ${ }^{\mathrm{INK} 4 \mathrm{a}}$ Immune Expression/Immunostaining and Human $\mathrm{Pa}$ pillomavirus DNA Test in Cervical Liquid-Based Cytological Samples. International Journal of Gynecological Cancer, 21, 79-85. http://dx.doi.org/10.1097/IGC.0b013e3182009eea

[60] Lee, J.W., Choi, C.H., Choi, J.J., Park, Y.A., Kim, S.J., Hwang, S.Y., Kim, W.Y., Lee, J.H., Kim, B.G. and Bae, D.S. (2008) Altered MicroRNA Expression in Cervical Carcinomas. Clinical Cancer Research, 14, 2535-2542. http://dx.doi.org/10.1158/1078-0432.CCR-07-1231

[61] Poiesz, B.J., Ruscetti, F.W., Gazdar, A.F., Bunn, P.A., Minna, J.D. and Gallo, R.C. (1980) Detection and Isolation of Type C Retrovirus Particles from Fresh and Cultured Lymphocytes of a Patient with Cutaneous T-Cell Lymphoma. Proceedings of the National Academy Science of the United States of America, 77, 7415-7419. http://dx.doi.org/10.1073/pnas.77.12.7415

[62] Uchiyama, T., Yodoi, J., Sagawa, K., Takatsuki, K. and Uchino, H. (1977) Adult T-Cell Leukemia: Clinical and Hematologic Features of 16 Cases. Blood, 50, 481-492.

[63] Yamaguchi, K., Nishimura, H., Kawano, F., Kohrogi, H., Jono, M., Miyamoto, Y., et al. (1983) A Proposal for Smoldering Adult T-Cell Leukemia-Diversity in Clinical Pictures of Adult T-Cell Leukemia. Japanese Journal of Clinical Oncology, 13, 189-199.

[64] Yamaguchi, K. and Takatsuki, K. (1993) 10 Adult T Cell Leukaemia-Lymphoma. Baillière’s Clinical Haematology, 6, 899-915. http://dx.doi.org/10.1016/S0950-3536(05)80183-0

[65] Peloponese, J.M., Yeung, M.L. and Jeang, K.T. (2006) Modulation of Nuclear Factor-кB by Human T Cell Leukemia Virus Type 1 Tax Protein: Implications for Oncogenesis and Inflammation. Immunology Research, 34, 1-12. http://dx.doi.org/10.1385/IR:34:1:1

[66] Kasai, T. and Jeang, K.T. (2004) Two Discrete Events, Human T-Cell Leukemia Virus Type I Tax Oncoprotein Expression and a Separate Stress Stimulus, Are Required for Induction of Apoptosis in T-Cells. Retrovirology, 1, 7.

[67] Kuo, Y.L. and Giam, C.Z. (2006) Activation of the Anaphase Promoting Complex by HTLV-1 Tax Leads to Senescence. The EMBO Journal, 25, 1741-1752. http://dx.doi.org/10.1093/carcin/bgi274

[68] Tabakin-Fix, Y., Azran, I., Schavinky-Khrapunsky, Y., Levy, O. and Aboud, M. (2006) Functional Inactivation of p53 by Human T-Cell Leukemia Virus Type 1 Tax Protein: Mechanisms and Clinical Implications. Carcinogenesis, 27, 673-681. http://dx.doi.org/10.1093/carcin/bgi274

[69] Proietti, F.A., Carneiro-Proietti, A.B., Catalan-Soares, B.C. and Murphy, E.L. (2005) Global Epidemiology of HTLV-I Infection and Associated Diseases. Oncogene, 24, 6058-6068. http://dx.doi.org/10.1038/sj.onc.1208968

[70] Asquith, B. and Bangham, C.R. (2008) How Does HTLV-I Persist Despite a Strong Cell-Mediated Immune Response? Trends in Immunology, 29, 4-11. http://dx.doi.org/10.1016/j.it.2007.09.006

[71] Feng, H., Shuda, M., Chang, Y. and Moore, P.S. (2008) Clonal Integration of a Polyomavirus in Human Merkel Cell Carcinoma. Science, 319, 1096-1100. http://dx.doi.org/10.1126/science.1152586

[72] Amber, K., McLeod, M.P. and Nouri, K. (2013) The Merkel Cell Polyomavirus and Its Involvementin Merkel Cell Carcinoma. Dermatologic Surgery, 39, 232-238. http://dx.doi.org/10.1111/dsu.12079

[73] Hourdequin, K.C., Lefferts, J.A., Brennick, J.B., Ernstoff, M.S., Tsongalis, G.J. and Pipas, J.M. (2013) Merkel Cell Polyomavirus and Extrapulmonary Small Cell Carcinoma. Oncology Letters, 6, 1049-1052.

[74] Tolstov, Y.L., Knauer, A., Chen, J.G., Kensler, T.W., Kingsley, L.A., Moore, P.S., et al. (2011) Asymptomatic Primary Merkel Cell Polyomavirus Infection among Adults. Emerging Infectious Disease, 17, 1371-1380. http://dx.doi.org/10.3201/eid1708.110079

[75] Engels, E.A., Frisch, M., Goedert, J.J., Biggar, R.J. and Miller, R.W. (2002) Merkel Cell Carcinoma and HIV Infection. The Lancet, 359, 497-498. http://dx.doi.org/10.1016/S0140-6736(02)07668-7

[76] Robak, E., Biernat, W., Krykowski, E., Jeziorski, A. and Robak, T. (2005) Merkel Cell Carcinoma in Apatient with BCell Chronic Lymphocytic Leukemia Treated with Cladribine Andrituximab. Leukemia \& Lymphoma, 46, 909-914. http://dx.doi.org/10.1080/10428190500057759 
[77] Wooff, J.C., Trites, J.R., Walsh, N.M. and Bullock, M.J. (2010) Complete Spontaneous Regression of Metastatic Merkel Cell Carcinoma: A Case Report and Review of the Literature. American Journal of Dermatopathology, 32, 614-617. http://dx.doi.org/10.1097/DAD.0b013e3181cd3158

[78] Harms, P.W., Patel, R.M., Verhaegen, M.E., Giordano, T.J., Nash, K.T., Johnson, C.N., et al. (2013) Distinct Gene Expression Profiles of Viral- and Nonviral-Associated Merkel Cell Carcinomarevealed by Transcriptome Analysis. Journal of Investigative Dermatology, 133, 936-945. http://dx.doi.org/10.1038/jid.2012.445

[79] Popp, S., Waltering, S., Herbst, C., Moll, I. and Boukamp, P. (2002) UV-B-Type Mutations and Chromosomal Imbalances Indicate Common Pathways for the Development of Merkel and Skin Squamous Cell Carcinomas. International Journal of Cancer, 99, 352-360. http://dx.doi.org/10.1002/ijc.10321

[80] Burgdorfer, W., Barbour, A.G., Hayes, S.F., Benach, J.L., Grunwaldt, E. and Davis, J.P. (1982) Lyme Disease-A Tick-Borne Spirochetosis? Science, 216, 1317-1319. http://dx.doi.org/10.1126/science.7043737

[81] Hovmark, A., Asbrink, E. and Olsson, I. (1986) The Spirochetal Etiology of Lymphadenosis Benigna Cutis Solitara. Acta Dermato Venereologica, 66, 479-484.

[82] Mitchell, P.D., Reed, K.D., Vandermause, M.F. and Melinski, J.W. (1993) Isolation of Borrelia burgdorferi from Skin Biopsy Specimens of Patients with Erythema Migrans. American Journal Clinical Pathology, 99, 104-107.

[83] Ashbrink, E. and Hovmark, H. (1985) Successful Cultivation of Spirochetes from Skin Lesions of Patients with Erythema Chronicum Migrans Afzelius and Acrodermatitis Chronica Atrophicans. Acta Pathologica Microbiologica Immunologica, 93, 161-163.

[84] Goos, M. (1971) Acrodermatitis Chronica Atrophicans and Malignant Lymphoma. Acta Dermato Venereolgica, 51, 457-459.

[85] Garbe, C., Stein, H., Dienemann, D. and Orfanos, C.E. (1991) Borrelia burgdorferi-Associated Cutaneous B Cell Lymphoma: Clinical and Immunohistologic Characterization of Four Cases. Journal of the American Academy of Dermatology, 24, 584-590. http://dx.doi.org/10.1016/0190-9622(91)70088-J

[86] Rijlaarsdam, J.U., Van der Putte, S.C.J., Berti, E., Kerl, H., Rieger, E., Toonstra, J., et al. (1993) Cutaneous Immunocytomas: A Clinicopathological Study of 26 Cases. Histopathology, 23, 117-125. http://dx.doi.org/10.1111/j.1365-2559.1993.tb00469.x

[87] Kutting, B., Bonsmann, G., Metze, D., Luger, T.A. and Cerroni, L. (1997) Borrelia burgdorferi—Associated Primary Cutaneous B-Cell Lymphoma: Complete Clearing of Skin Lesions after Antibiotic Pulse Therapy or Intralesional Injection of Interferon Alfa-2a. Journal of the American Academy of Dermatology, 36, 311-314. http://dx.doi.org/10.1016/S0190-9622(97)80405-7

[88] Cerroni, L., Zöchling, N., Putz, B. and Kerl, H. (1997) Infection by Borrelia burgdorferi and Cutaneous B-Cell Lymphoma. Journal of Cutaneous Pathology, 24, 457-461. http://dx.doi.org/10.1111/j.1600-0560.1997.tb01318.x

[89] Roggero, E., Zucca, E., Mainetti, C., Bertoni, F., Valsangiacomo, C., Pedrinis, E., et al. (2000) Eradication of Borrelia burgdorferi Infection in Primary Marginal Zone B-Cell Lymphoma of the Skin. Human Pathology, 31, $263-268$. http://dx.doi.org/10.1016/S0046-8177(00)80233-6

[90] Hirschfeld, M., Kirschning, C.J., Schwandner, R., Wesche, H., Weis, J.H., Wooten, R.M., et al. (1999) Cutting Edge: Inflammatory Signaling by Borrelia burgdorferi Lipoproteins Is Mediated by Toll-Like Receptor 2. Journal of Immunology, 163, 2382-2386.

[91] Grayston, J.T. (1994) Chlamydia pneumoniae (TWAR) Infections in Children. Pediatric Infectious Disease Journal, 13, 675-684. http://dx.doi.org/10.1097/00006454-199408000-00001

[92] Everett, K.D.E., Bush, R.M. and Andersen, A.A. (1999) Emended Description of the Order Chlamydiales, Proposal of Parachlamydiaceae fam. nov. and Simkaniaceae fam. nov., Each Containing One Monotypic Genus, Revised Taxonomy of the Family Chlamydiaceae, Including a New Genus and Five New Species, and Standards for the Identification of Organisms. International Journal of Systematic Evolutionary Microbiology, 49, 415-440.

[93] Thom, D.H. and Grayston, J.T. (1991) Infections with Chlamydia pneumoniae Strain TWAR. Clinics of Chest Medicine, 12, 245-256.

[94] Wolf, K. and Fields, K.A.C. (2013) Chlamydia pneumoniae Impairs the Innate Immune Response in Infected Epithelial Cells by Targeting TRAF3. Journal of Immunology, 190, 1695-1701. http://dx.doi.org/10.4049/jimmunol.1202443

[95] Laurila, A.L., Anttila, T., Läärä, E., Bloigu, A., Virtamo, J., Albanes, D., et al. (1997) Serological Evidence of an Association between Chlamydia pneumoniae Infection and Lung Cancer. International Journal of Cancer, 74, 31-34.

[96] Preston-Martin, S., Pike, M.C., Ross, R.K., Jones, P.A. and Henderson, B.E. (1990) Increased Cell Division as a Cause of Human Cancer. Cancer Research, 50, 7415-7421.

[97] von Hertzen, L.C. (1998) Chlamydia pneumoniae and Its Role in Chronic Obstructive Pulmonary Disease. Annals of Medicine, 30, 27-37. http://dx.doi.org/10.3109/07853899808999382 
[98] Koyi, H., Brandén, E., Gnarpe, J., Gnarpe, H, Arnholm, B. and Hillerdal, G. (1999) Chlamydia pneumoniae May Be Associated with Lung Cancer. Preliminary Report on a Seroepidemiological Study. APMIS, 107, 828-832. http://dx.doi.org/10.1111/j.1699-0463.1999.tb01478.x

[99] Blaser, M.J. and Atherton, J.C. (2004) Helicobacter pylori Persistence: Biology and Disease. Journal Clinical Investigation, 113, 321-333. http://dx.doi.org/10.1172/JCI20925

[100] Parsonnet, J., Friedman, G.D., Orentreich, N. and Vogelman, H. (1997) Risk for Gastric Cancer in People with CagA Positive or CagA Negative Helicobacter pylori Infection. Gut, 40, 297-301. http://dx.doi.org/10.1136/gut.40.3.297

[101] Taylor, D.N. and Blaser, M.J. (1991) The Epidemiology of Helicobacter pvlori Infections. Epidemiology Review, 13, 42-59.

[102] Akopyanz, N., Bukanov, N.O., Westblom, T.U., Kresovich, S. and Berg, D.E. (1992) DNA Diversity among Clinical Isolates of Helicobacler-pvlori Detected by PCR-Based RAPD Fingerprinting. Nucleic Acids Research, 20, 5137-5142. http://dx.doi.org/10.1093/nar/20.19.5137

[103] Fujimoto, S., Marshall, B. and Blaser, M.J. (1994) PCR-Based Restriction Fragment Length Polymorphism Typing of Helicobacter pvlori. Journal of Clinical Microbiology, 32, 331-334.

[104] Prewett, E.J., Bickley, J., Owen, R.J. and Pounder, R.E. (1992) DNA Patterns of Helicobacter pvlori Isolated from Gastric Antrum, Body, and Duodenum. Gastroenterology, 702, 829-833.

[105] Graham, D.Y., Opekun, A.R., Osato, M.S., El-Zimaity, H.M., Lee, C.K., Yamaoka, Y., Qureshi, W.A., Cadoz, M. and Monath, T.P. (2004) Challenge Model for Helicobacter pylori Infection in Human Volunteers. Gut, 53, 1235-1243. http://dx.doi.org/10.1136/gut.2003.037499

[106] Nurgalieva, Z.Z., Conner, M.E., Opekun, A.R., Zheng, C.Q., Elliott, S.N., Ernst, P.B., Osato, M., Estes, M.K. and Graham, D.Y. (2005) B-Cell and T-Cell Immune Responses to Experimental Helicobacter pylori Infection in Humans. Infectious Immunology, 73, 2999-3006. http://dx.doi.org/10.1128/IAI.73.5.2999-3006.2005

[107] Jones, P.A. and Baylin, S.B. (2007) The Epigenomics of Cancer. Cell, 128, 683-692. http://dx.doi.org/10.1016/j.cell.2007.01.029

[108] Lu, H., Ouyang, W. and Huang, C. (2006) Inflammation, a Key Event in Cancer Development. Molecular Cancer Research, 4, 221-233. http://dx.doi.org/10.1158/1541-7786.MCR-05-0261

[109] Maekita, T., Nakazawa, K., Mihara, M., Nakajima, T., Yanaoka, K., Iguchi, M., et al. (2006) High Levels of Aberrant DNA Methylation in Helicobacter pylori-Infected Gastric Mucosae and Its Possible Association with Gastric Cancer Risk. Clinical Cancer Research, 12, 989-995. http://dx.doi.org/10.1158/1078-0432.CCR-05-2096

[110] Nakajima, T., Maekita, T., Oda, I., Gotoda, T., Yamamoto, S., Umemura, S., et al. (2006) Higher Methylation Levels in Gastric Mucosae Significantly Correlate with Higher Risk of Gastric Cancers. Cancer Epidemiology, Biomarkers \& Prevention, 15, 2317-2321. http://dx.doi.org/10.1158/1055-9965.EPI-06-0436

[111] Razin, S., Yogev, D. and Naot, Y. (1998) Molecular Biology and Pathogenicity of Mycoplasmas. Microbiology and Molecular Biology Reviews, 62, 1094-1156.

[112] Sun, G., Xu, X., Wang, Y., Shen, X., Chen, Z. and Yang, J. (2008) Mycoplasma pneumoniae Infection Induces Reactive Oxygen Species and DNA Damage in A549 Human Lung Carcinoma Cells. Infectious Immunology, 76, 44054413. http://dx.doi.org/10.1128/IAI.00575-08

[113] Feng, S.H., Tsai, S., Rodriguez, J. and Lo, S.C. (1999) Mycoplasmal Infections Prevent Apoptosis and Induce Malignant Transformation of Interleukin-3-Dependent 32D Hematopoietic Cells. Molecular Cell Biology, 19, 7995-8002.

[114] Gong, M., Meng, L., Jiang, B., Zhang, J., Yang, H., Wu, J. and Shou, C. (2008) p37 from Mycoplasma hyorhinis Promotes Cancer Cell Invasiveness and Metastasis through Activation of MMP-2 and Followed by Phosphorylation of EGFR. Molecular Cancer Therapeutics, 7, 530-537. http://dx.doi.org/10.1158/1535-7163.MCT-07-2191

[115] Jiang, S., Zhang, S., Langenfeld, J., Lo, S.C. and Rogers, M.B. (2008) Mycoplasma Infection Transforms Normal Lung Cells and Induces Bone Morphogenetic Protein 2 Expression by Posttranscriptional Mechanisms. Journal of Cellular Biochemistry, 104, 580-594. http://dx.doi.org/10.1002/jcb.21647

[116] Namiki, K., Goodison, S., Porvasnik, S., Allan, R.W., Iczkowski, K.A., Urbanek, C., Reyes, L., Sakamoto, N. and Rosser, C.J. (2009) Persistent Exposure to Mycoplasma Induces Malignant Transformation of Human Prostate Cells. PLOS ONE, 4, e6872.

[117] Pehlivan, M., Pehlivan, S., Onay, H., Koyuncuoglu, M. and Kirkali, Z. (2005) Can Mycoplasma-Mediated Oncogenesis Be Responsible for Formation of Conventional Renal Cell Carcinoma? Urology, 65, 411-414. http://dx.doi.org/10.1016/j.urology.2004.10.015

[118] Tsai, S., Wear, D.J., Shih, J.W. and Lo, S.C. (1995) Mycoplasmas and Oncogenesis: Persistent Infection and Multistage Malignant Transformation. Proceedings of the National Academy of Science of the United States of America, 92 10197-10201. http://dx.doi.org/10.1073/pnas.92.22.10197 
[119] Logunov, D.Y., Scheblyakov, D.V., Zubkova, O.V., Shmarov, M.M., Rakovskaya, I.V., Gurova, K.V., Tararova, N.D., Burdelya, L.G., Naroditsky, B.S., Ginzburg, A.L. and Gudkov, A.V. (2008) Mycoplasma Infection Suppresses p53, Activates NF-kappaB and Cooperates with Oncogenic Ras in Rodent Fibroblast Transformation. Oncogene, 27, 45214531. http://dx.doi.org/10.1038/onc.2008.103

[120] Waterhouse, J., Muir, C., Correa, P. and Powell, J. (1976) Cancer Incidence in Five Continents, Vol. 3. IARC Scientific Publications, No. 15, IARC, Lyon.

[121] Myers, M.H. and Ries, L.A. (1989) Cancer Patient Survival Rates: SEER Program Results for 10 Years of Follow-Up. CA: A Cancer Journal for Clinicians, 39, 21-32. http://dx.doi.org/10.3322/canjclin.39.1.21

[122] Strom, B.L., Nelson, W.L., Henson, D.E., et al. (1985) Carcinoma of the Gallbladder. In: Cohen, S. and Soloway, R.D., Eds., Gallstones, Churchill Livingstone, New York, 275-278.

[123] Kar, P., Kumar, R., Kapur, B.M., Tandon, B.N. and Tandon, R.K. (1986) Surgical Obstructive Jaundice in India: A Clinical Profile. Journal of the Association of Physicians of India, 34, 115-118.

[124] Delhi Cancer Registry (1993) Institute of Rotary Cancer Hospital, All India Institute of Medical Sciences, 29.

[125] Kimura, W., Shimada, H., Kuroda, A. and Morioka, Y. (1989) Carcinoma of the Gallbladder and Extrahepatic Bile Duct in Autopsy Cases of the Aged, with Special Reference to Its Relationship to Gallstones. American Journal of Gastroenterology, 84, 386-390.

[126] Fraumeni Jr., J.F. (1975) Cancers of the Pancreas and Biliary Tract: Epidemiological Considerations. Cancer Research, 35, 3437-3446.

[127] Caygill, C.P., Hill, M.J., Braddick, M. and Sharp, J.C.M. (1994) Cancer Mortality in Chronic Typhoid and Paratyphoid Carriers. The Lancet, 343, 83-84. http://dx.doi.org/10.1016/S0140-6736(94)90816-8

[128] Hill, M.J. (1995) Chronic Bacterial Infection and Subsequent Human Carcinogenesis. European Journal of Cancer Prevention, 4, 127-128. http://dx.doi.org/10.1097/00008469-199504000-00001

[129] Chipman, J.K. (1982) Bile as a Source of Potential Reactive Metabolites. Toxicology, 25, 99-111. http://dx.doi.org/10.1016/0300-483X(82)90022-1

[130] Akhemedov, D.R. (1994) The Status of the Blood Antioxidant System in a Chronic Typhoid Bacterial Carrier State. Zhurnal Mikrobiologii, Epidemiologii i Immunobiolgii, 1, 91-95.

[131] Carter, P.B. and Collins, F.M. (1975) Peyer’s Patch Responsiveness to Salmonella in Mice. Journal of the Reticuloendothelial Society, 17, 38-46.

[132] Monack, D.M., Bouley, D.M. and Falkow, S. (2004) Salmonella typhimurium Persists within Macrophages in the Mesenteric Lymph Nodes of Chronically Infected Nramp $1^{+/+}$Mice and Can Be Reactivated by IFN $\gamma$ Neutralization. Journal of Experimental Medicine, 199, 231-241. http://dx.doi.org/10.1084/jem.20031319

[133] Wilson, W.R., Thompson, R.L., Wilkowske, C.J., Washington, J.A., Giuliani, E.R. and Geraci, J.E. (1981) Short-Term Therapy for Streptococcal Infective Endocarditis. Combined Intramuscular Administration of Penicillin and Streptomycin. JAMA, 245, 360-363. http://dx.doi.org/10.1001/jama.1981.03310290028017

[134] Reynolds, J.G., Silva, E. and McCormack, W.M. (1983) Association of Streptococcus bovisbacteremia with Bowel Disease. Journal of Clinical Microbiology, 17, 696-697.

[135] Leport, C., Bure, A., Leport, J. and Vilde, J.L. (1987) Incidence of Colonic Lesions in Streptococcus bovis and Enterococcal Endocarditis. The Lancet, 1, 748. http://dx.doi.org/10.1016/S0140-6736(87)90391-6

[136] Zarkin, B.A., Lillemoe, K.D., Cameron, J.L., Effron, P.N., Magnuson, T.H. and Pitt, H.A. (1990) The Triad of Streptococcus bovis Bacteremia, Colonic Pathology, and Liver Disease. Annals of Surgery, 211, 786-791. http://dx.doi.org/10.1097/00000658-199006000-00019

[137] Kok, H., Jureen, R., Soon, C.Y. and Tey, B.H. (2007) Colon Cancer Presenting as Streptococcus gallolyticus Infective Endocarditis. Singapore Medical Journal, 48, 43-45.

[138] Malkin, J., Kimmitt, P.T., Ou, H.Y., Bhasker, P.S., Khare, M., Deng, Z., Stephenson, I., Sosnowski, A.W., Perera, N. and Rajakumar, K. (2008) Identification of Streptococcus gallolyticus subsp. Macedonicus as the Etiological Agent in a Case of Culture-Negative Multivalve Infective Endocarditis by 16S rDNA PCR Analysis of Resected Valvular Tissue. Journal of Heart Valve Disease, 17, 589-592.

[139] Gupta, A., Madani, R. and Mukhtar, H. (2010) Streptococcus bovis Endocarditis, a Silent Sign for Colonic Tumour. Colorectal Disease, 12, 164-171. http://dx.doi.org/10.1111/j.1463-1318.2009.01814.x

[140] Parsonnet, J. (1995) Bacterial Infection as a Cause of Cancer. Environmental Health Perspective, 103, 263-268.

[141] Miki, C., Tanaka, K., Toiyama, Y., Inoue, Y., Uchida, K., Mohri, Y. and Kusunoki, M. (2010) Comparison of the Prognostic Value of Inflammation-Based Pathologic and Biochemical Criteria in Patients Undergoing Potentially Curative Resection for Colorectal Cancer. Annals of Surgery, 251, 389-390.

http://dx.doi.org/10.1097/SLA.0b013e3181cb8b31 
[142] International Agency for Research on Cancer (1994) Infection with Liver Flukes (Opisthorchis viverrini, Opisthorchis felineus and Clonorchis sinensis). IARC Monographs on the Evaluation of Carcinogenic Risks to Humans, 61, 121175.

[143] Sun, T. (1984) Pathology and Immunology of Clonorchis sinensis Infection in the Liver. Annals Clinical Lab Science, 14, 208-215.

[144] Higginson, J. (1995) Relation of Carcinoma of the Liver to Cirrhosis, Malaria, Syphilis and Parasitic Disease. Schweizerische Zeitschrift für Pathologie und Bakteriologie. Revue suisse de pathologie et de bactériologie, 18, 625-643.

[145] Lee, S.H., Shim, T.S., Lee, S.M. and Chi, J.G. (1978) Studies on Pathological Changes of the Liver in Albino Rats Infected with Clonorchis sinensis. Korean Journal Parasitology, 16, 148-155. http://dx.doi.org/10.3347/kjp.1978.16.2.148

[146] Monroe, L.S. (1995) Gastrointestinal Parasites. In: Haubrich, W.S., Schaffner, F. and Berk, J.E., Eds., Bockus Gastroenterology, The W. B. Saunders Co., Philadelphia, 3181-3183.

[147] Ona, F.V. and Dytoc, J.N. (1991) Clonorchis-Associated Cholangiocarcinoma: A Report of Two Cases with Unusual Manifestations. Gastroenterology, 101, 831-839.

[148] Braconi, C. and Patel, T. (2010) Cholangiocarcinoma: New Insights into Disease Pathogenesis and Biology. Infectious Disease Clinics of North America, 24, 871-884. http://dx.doi.org/10.1016/j.idc.2010.07.006

[149] Braconi, C. (2010) Cholangiocarcinoma: New Insights into Disease Pathogenesis and Biology. Infectious Disease Clinics of North America, 24, 871-884. http://dx.doi.org/10.1016/j.idc.2010.07.006

[150] Hong, S.T. and Fang, Y. (2012) Clonorchis sinensis and Clonorchiasis, an Update. Parasitology International, 61, 1724. http://dx.doi.org/10.1016/j.parint.2011.06.007

[151] Keiser, J. and Utzinger, J. (2009) Food-Borne Trematodiases. Clinical Microbiology Reviews, 22, 466-483. http://dx.doi.org/10.1128/CMR.00012-09

[152] IARC (1994) Schistosomes, Liver Flukes and Helicobacter pylori. IARC Working Group on the Evaluation of Carcinogenic Risks to Humans. Lyon, 7-14 June 1994. IARC Monographs on the Evaluation of Carcinogenic Risks to Humans, 61, 1-241

[153] Sripa, B., Kaewkes, S., Sithithaworn, P., Mairiang, E., Laha, T., Smout, M., et al. (2007) Liver Fluke Induces Cholangiocarcinoma. PLoS Medicine, 4, e201. http://dx.doi.org/10.1371/journal.pmed.0040201

[154] Thamavit, W., Pairojkul, C., Tiwawech, D., Shirai, T. and Ito, N. (1994) Strong Promoting Effect of Opisthorchis viverrini Infection on Dimethylnitrosamine-Initiated Hamster Liver. Cancer Letters, 78, 121-125. http://dx.doi.org/10.1016/0304-3835(94)90040-X

[155] Vatanasapt, V.S.B., Sithithaworn, P. and Mairiang, P. (1999) Liver Flukes and Liver Cancer. Cancer Surveys, 33, 313343.

[156] Thamavit, W., Bhamarapravati, N., Sahaphong, S., Vajrasthira, S. and Angsubhakorn, S. (1978) Effects of Dimethylnitrosamine on Induction of Cholangiocarcinoma in Opisthorchis viverrini-Infected Syrian Golden Hamsters. Cancer Research, 38, 4634-4639.

[157] Bissell, M.J. and Radisky, D. (2001) Putting Tumours in Context. Nature Review Cancer, 1, 46-54. http://dx.doi.org/10.1038/35094059

[158] Webb, G. (1981) The Six Diseases of WHO. Schistosomiasis: Some Advances. British Medical Journal, 283, 11041106. http://dx.doi.org/10.1136/bmj.283.6299.1104

[159] World Health Organization (1985) The Control of Schistosomiasis. Report of a WHO Expert Committee. WHO Technical Report Series, 728, 1-113.

[160] World Health Organization (1987) Progress in Assessment of Morbidity Due to Schistosoma haematobium Infection. A Review of Recent Literature. WHO Technical Report Series, 87, 91.

[161] Escobedo, G., Roberts, C.W., Carrero, J.C. and Morales-Montor, J. (2005) Parasite Regulation by Host Hormones: An Old Mechanism of Host Exploitation? Trends in Parasitology, 21, 588-593. http://dx.doi.org/10.1016/j.pt.2005.09.013

[162] Tawfik, H.N. (1988) Carcinoma of the Urinary bladder Associated with Schistosomiasis in Egypt: The Possible Causal Relationship. In: Miller, R.W., Ed., Unusual Occurrences as Clues to Cancer Etiology, Japanese Science Society Press, Tokyo, 197-209.

[163] Makhyoun, N.A. (1974) Smoking and Bladder Cancer in Egypt. British Journal of Cancer, 30, 577-581. http://dx.doi.org/10.1038/bjc.1974.238

[164] El-Merzabani, M.M., El-Aaser, A.A. and Zakhary, N.I. (1979) A Study on the Aetiological Factors of Bilharzial Bladder Cancer in Egypt. 1. Nitrosamines and Their Precursors in Urine. European Journal of Cancer, 15, 287-291. http://dx.doi.org/10.1016/0014-2964(79)90039-2 
[165] Hicks, R.M. (1982) Nitrosamines as Possible Etiological Agents in Bilharzial Bladder Cancer. In: Magee, P.N., Ed., Banbury Report Number 12: Nitrosamines and Human Cancer, Cold Spring Harbor Laboratory Press, Cold Spring Harbor, 455-471.

[166] Tricker, A.R., Mostafa, M.H., Speiglhalder, B. and Preussmann, R. (1989) Urinary Excretion of Nitrate, Nitrite and $N$ Nitroso Compounds in Schistosomiasis and Bladder Cancer Patients. Carcinogenesis, 10, 547-552. http://dx.doi.org/10.1093/carcin/10.3.547

[167] Badawi, A.F., Mostafa, M.H., Aboul-Azm, T., Haboubi, N.Y., O’Connor, P.J. and Cooper, D.P. (1992) Promutagenic Methylation Damage in Bladder DNA from Patients with Bladder Cancer Associated with Schistosomiasis and from Normal Individuals. Carcinogenesis, 13, 877-881. http://dx.doi.org/10.1093/carcin/13.5.877

[168] IARC (2002) Monographs on the Evaluation of Carcinogenic Risks in Humans. International Agency for Research on Cancer (IARC). IARC Press, Lyon, Vol. 82.

[169] Williams, J.H., Phillips, T.D., Jolly, P.E., Stiles, J.K., Jolly, C.M. and Aggarwal, D. (2004) Human Aflatoxicosis in Developing Countries: A Review of Toxicology, Exposure, Potential Health Consequences, and Interventions. American Journal of Clinical Nutrition, 80, 1106-1122.

[170] IARC (2002) Some Traditional Herbal Medicines, Some Mycotoxins, Naphthalene and Styrene. IARC Press, Lyon.

[171] Ferlay, J., Shin, H., Bray, F., Forman, D., Mathers, C. and Parkin, D.M. (2010) Estimates of Worldwide Burden of Cancer in 2008: GLOBOCAN 2008. International Journal of Cancer, 127, 2893-2917. http://dx.doi.org/10.1002/ijc.25516

[172] Jemal, A., Bray, F., Center, M.M., Ferlay, J., Ward, E. and Forman, D. (2011) Global Cancer Statistics. CA: A Cancer Journal for Clinicians, 61, 69-90. http://dx.doi.org/10.3322/caac.20107

[173] Bressac, B., Kew, M.C., Wands, J. and Ozturk, M. (1991) Selective G to T Mutations of p53 Gene in Hepatocellular Carcinoma from Southern Africa. Nature, 350, 429-431. http://dx.doi.org/10.1038/350429a0

[174] Hsu, I.C., Metcalf, R.A., Sun, T., Welsh, J.A., Wang, N.J. and Harris, C.C. (1991) Mutational Hotspot in the p53 Gene in Human Hepatocellular Carcinomas. Nature, 350, 427-428. http://dx.doi.org/10.1038/350427a0

[175] Kirk, G.D., Lesi, O.A., Mendy, M., Szymañska, K., Whittle, H., Goedert, J.J., et al. (2005) $249^{\text {Ser }}$ TP53 Mutation in Plasma DNA, Hepatitis B Virus Infection, and Risk of Hepatocellular Carcinoma. Oncogene, 24, 5858-5867. http://dx.doi.org/10.1038/sj.onc.1208732

[176] Wang, L.Y., Hatch, M., Chen, C.J., Levin, B., You, S.L., Lu, S.N., et al. (1996) Aflatoxin Exposure and Risk of Hepatocellular Carcinoma in Taiwan. International Journal of Cancer, 67, 620-625.

[177] Ozturk, M., Bressac, B., Pusieux, A., et al. (1991) A p53 Mutational Hotspot in Primary Liver Cancer Is Geographically Localised in High Aatoxin Areas of the World. The Lancet, 338, 260-265.

[178] Coursaget, P., Depril, N., Chabaud, M., Nandi, R., Mayelo, V., LeCann, P., et al. (1993) High Prevalence of Mutations at Codon 249 of the p53 Gene in Hepatocellular Carcinoma from Senegal. British Journal of Cancer, 67, 1395-1397. http://dx.doi.org/10.1038/bjc.1993.258

[179] Puisieux, A., Lim, S., Groopman, J. and Ozturk, M. (1991) Selective Targeting of p53 Gene Mutational Hotspots in Human Cancers by Etiologically Defined Carcinogens. Cancer Research, 51, 6185-6189.

[180] Corthay, A. (2014) Does the Immune System Naturally Protect against Cancer? Frontiers in Immunology, 5, 1-8.

[181] Rochford, R., Cannon, M.J. and Moormann, A.M. (2005) Endemic Burkitt’s Lymphoma: A Polymicrobial Disease? Nature Reviews Microbiology, 3, 182-187. http://dx.doi.org/10.1038/nrmicro1089

[182] Thorley-Lawson, D.A. and Allday, M.J. (2008) The Curious Case of the Tumour Virus: 50 Years of Burkitt's Lymphoma. Nature Reviews Microbiology, 6, 913-924. http://dx.doi.org/10.1038/nrmicro2015

[183] Murray, P.R., Rosenthal, K.S. and Pfaller, M.A. (2009) Mycotoxins and Mycotoxicoses: Medical Microbiology. Elsevier, Amsterdam, 211-216.

[184] Wijaya, I. and Hasan, I. (2013) Reactivation of Hepatitis B Virus Associated with Chemotherapy and Immunosuppressive Agents. Acta Medica Indonesiana, 45, 61-66. 
Scientific Research Publishing (SCIRP) is one of the largest Open Access journal publishers. It is currently publishing more than 200 open access, online, peer-reviewed journals covering a wide range of academic disciplines. SCIRP serves the worldwide academic communities and contributes to the progress and application of science with its publication.

Other selected journals from SCIRP are listed as below. Submit your manuscript to us via either submit@scirp.org or Online Submission Portal.
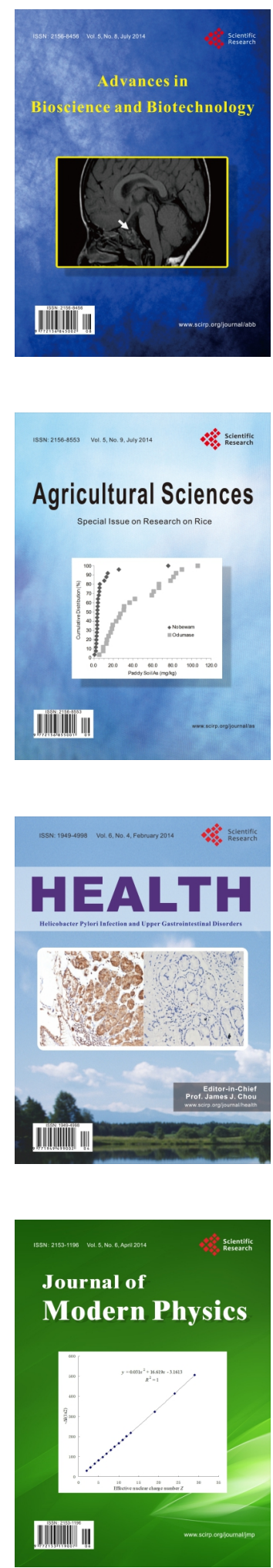
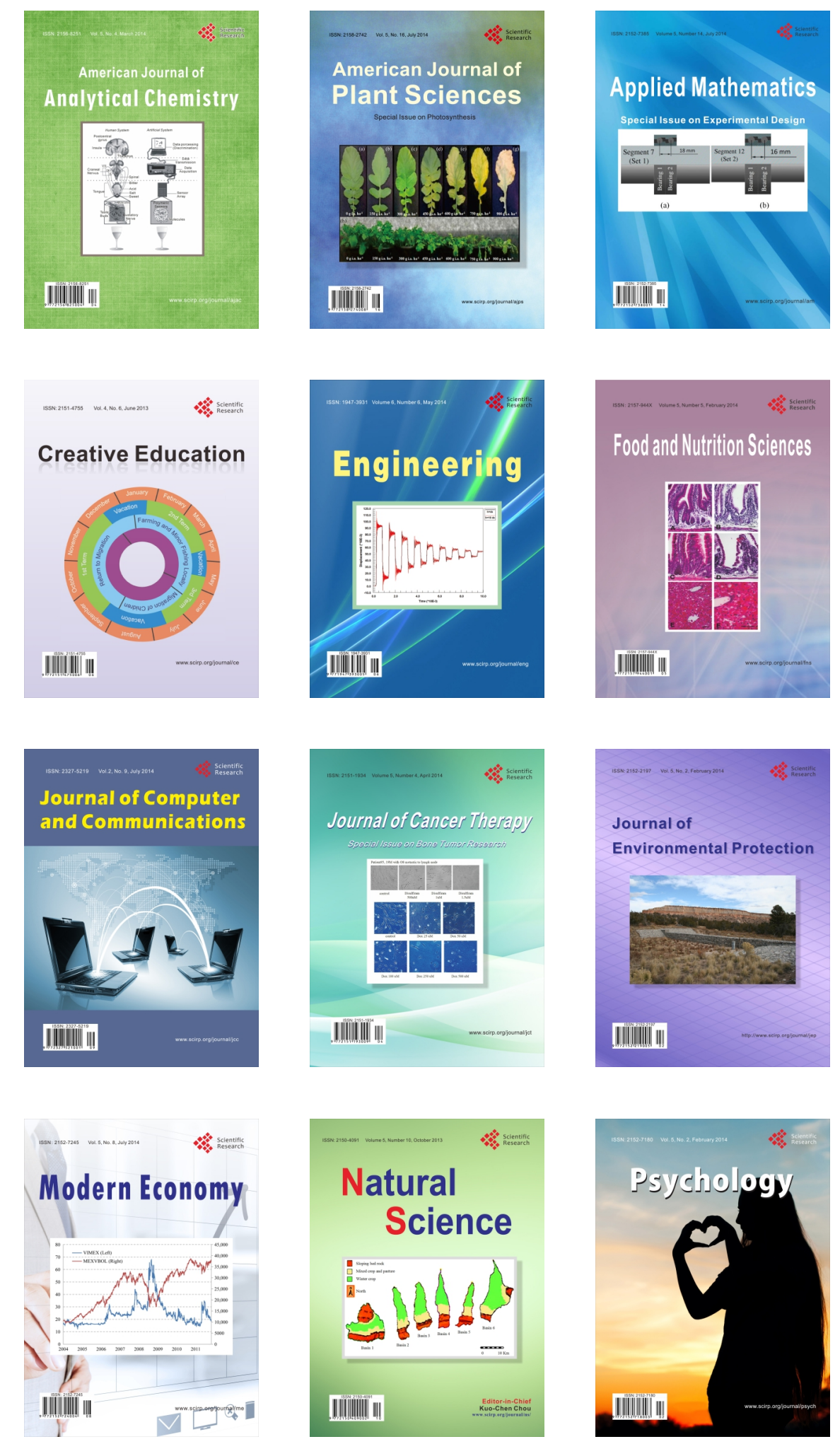